DOI https://doi.org/10.30525/978-9934-26-038-4-22

\title{
FAMILY PHYSICIAN STRATEGIES THAT CAN HELP STRENGTHEN ADHERENCE TO TREATMENT AND QUALITY OF LIFE OF PATIENTS WITH COMORBID PATHOLOGY
}

\author{
Kuznetsova L. P. \\ Doctor of Medical Sciences, Professor, \\ Professor at Department of General Practice-Family Medicine, \\ Gastroenterology, Physical and Rehabilitation Medicine \\ State Institution "Zaporizhzhya Medical Academy \\ of Postgraduate Education Ministry of Health of Ukraine»
}

Bondar M. V.

Postgraduate Student at the Department of General Practice-Family Medicine, Gastroenterology, Physical and Rehabilitation Medicine

State Institution «Zaporizhzhya Medical Academy of Postgraduate Education Ministry of Health of Ukraine»

\section{Strogonova T. V.}

Ph. D.,

Associate Professor at Department of Medical Physics,

Biophysics and Higher Mathematics

Zaporizhzhya State Medical University

\section{Bogoslav T. V.}

Ph. D.,

Associate Professor at the Internal Medicine № 1 and Simulation Medicine

Zaporizhzhya State Medical University

Zaporizhzhya, Ukraine

In modern medicine there is a change in the paradigm of treatment, the purpose of which is the use of special treatment methods and personalized prevention plans, unique to each patient.

In this regard, it is important to study methods that promote the implementation of the principles of personalized medicine, the interaction of family physician and patient, and monitoring the effectiveness of treatment, in particular, such as adherence to treatment and quality of life. This is especially important for comorbid pathologies. 
Osteoarthritis (OA) and hypertension (HP) are the most common chronic joint disease, occurring in more than $10-20 \%$ of the world's population and correlating with age [1], [2].

$\mathrm{OA}$ is characterized by pain, significant structural changes in the joints and functional disorders. Pain syndrome in this disease is the main reason for patients to seek medical help from a family doctor and causes not only significant temporary disability of young and middle-aged people, but also early disability. All of the above significantly affects the quality of life (QOL) of patients. According to recent studies, OA is the most common hypertension (HP), which is also the most common pathology of cardiovascular disease (CVD) worldwide [3], [4].

The analysis allowed to determine the main strategies of the family doctor in communication with a patient with osteoarthritis with poor pathology: patient education, improvement of medication, improving the environment between patient and doctor, improving patient care. These strategies and their combinations can be used in practice to strengthen adherence to treatment of patients with comorbid pathology.

Table 1

Family physician strategies that can help strengthen adherence to treatment of patients with comorbid pathology

\begin{tabular}{|c|c|}
\hline Type of strategy & Specialized strategies \\
\hline Patient education & $\begin{array}{c}\text { The doctor's interest during the diagnosis } \\
\text { The advantage of face-to-face meetings } \\
\text { with the patient } \\
\text { Creating an environment of trust between } \\
\text { doctor and patient } \\
\text { Feedback }\end{array}$ \\
\hline $\begin{array}{l}\text { Improving medication } \\
\text { mode }\end{array}$ & $\begin{array}{c}\text { Simplification of treatment } \\
\text { The use of pill boxes } \\
\text { Dosage once a day } \\
\text { Combined recipes } \\
\text { Increasing the dose is better than introducing } \\
\text { other treatments } \\
\text { Application of } 90 \text { days drug support }\end{array}$ \\
\hline $\begin{array}{l}\text { Improving patient- } \\
\text { physician interaction }\end{array}$ & $\begin{array}{l}\text { Discussion of risks, side effects and prefer- } \\
\text { ences of drug treatment } \\
\text { Using a patient-centered approach }\end{array}$ \\
\hline $\begin{array}{l}\text { Improving } \\
\text { patient care }\end{array}$ & $\begin{array}{l}\text { Application of Telemedicine methods } \\
\text { Using by patients f self-management tools, } \\
\text { f.e. Diary for self-observation } \\
\text { Use of the lowest cost drugs } \\
\text { Use of medication reminders }\end{array}$ \\
\hline
\end{tabular}


As part of these strategies, in order to improve the control of the effectiveness of treatment of patients with comorbid flow, it is recommended to use the Moriski-Green questionnaire to increase adherence to treatment, which provides not only short-term effect but also long-term impact on disease prognosis.

It has also been proven that the use of the SF-36 questionnaire for integrated assessment of patients with comorbid pathology can be an effective method of implementing strategies and the key to a personalized treatment strategy.

\section{References:}

1. Особенности функционирования митохондрий миокарда у крыс со спонтанной гипертензией (SHR) на фоне экспериментального сахарного диабета и атеросклероза МЮ Колесник, ИФ Беленичев, ГВ Дзяк, ИС Чекман - Запорожский медицинский журнал, 2012.

2. Features of arterial hypertension course in patients with psoriasis [Текст] = Особливості перебігу артеріальної гіпретензії у хворих на псоріаз / V. A. Vizir, G. I. Makurina // Запорожский медицинский журнал. - 2017. - Т. 19, N 2. - С. 129-134. - doi: 10.14739/2310-1210. 2017.2.95559. - ISSN 2306-4145.

3. Kolesnyk M. Yu. Reliability of two-dimensional speckle tracking echocardiography in assessment of left atrial function in postmenopausal hypertensive women / M. Yu. Kolesnyk, M. V. Sokolova // Запорож. мед. журн. - 2018. - Т. 20, № 1(106). - C. 19-25. DOI: 10.14739/2310-1210. 2018.1.121875.

4. Wenham C.Y., Conaghan P.G. New horizons in osteoarthritis. Age Ageing, 2013. Vol. 42(3). P. 272-278.

5. Діференційований підхід до лікування остеоартрозу 3 коморбідною патологією./ Шуба Н.М. та ін. Український ревматологічний журнал. 2017. № 4. С. 6-16. 